\title{
Microcephaly in infantile Sandhoff's disease
}

\author{
Kaushik Maulik, ${ }^{1}$ Santhosh Kumar, ${ }^{1}$ Paramjeet Singh, ${ }^{2}$ Arushi Gahlot Saini ${ }^{1}$
}

${ }^{1}$ Department of Pediatrics, Postgraduate Institute of Medical Education and Research, Chandigarh, Chandigarh UT, India ${ }^{2}$ Department of Radiodiagnosis, Postgraduate Institute of Medical Education and Research, Chandigarh, Chandigarh UT, India

\section{Correspondence to} Dr Arushi Gahlot Saini doctorarushigahlot@gmail.com

Accepted 7 June 2017

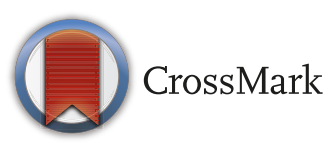

To cite: Maulik K, Kumar S, Singh P, et al. BMJ Case Rep Published Online First: [please include Day Month Year]. doi:10.1136/bcr-2017220912

\section{DESCRIPTION}

We evaluated a boy aged 16 months with developmental arrest at the age of 6 months followed by neuroregression and recurrent generalised seizures. Perinatal and family history was not contributory. He was first born to non-consanguineous parents by term, uncomplicated vaginal delivery and weighed $2.8 \mathrm{~kg}$ at birth. On examination, he was unable to hold neck, fixate, coo or smile and showed no interest in the surroundings. His weight was $9.5 \mathrm{~kg}$ (between 15th and 50th centile), length $78 \mathrm{~cm}$ (between 15 th and 50th centile) and head circumference $44.4 \mathrm{~cm}$ (below $3 \mathrm{rd}$ centile) with normal head circumference of father $(54 \mathrm{~cm})$ and mother $(51 \mathrm{~cm})$. He also had hyperacusis, bilateral cherry-red spot, generalised hypotonia, brisk muscle stretch reflexes, bilateral Babinski's sign and no organomegaly. In view of infantile-onset neuroregression, microcephaly, seizures, cherry-red spot and spasticity, clinical diagnoses of GM2 (Tay-Sach's and Sandhoff's disease), GM1 gangliosidosis and Krabbe's disease were considered initially. Skull radiograph showed J-shaped sella turcica (figure 1A). CT scan of brain showed bilateral thalamic hyperdensity (figure 1B). MRI of the brain showed bilateral thalamic T2/fluid-attenuated inversion recovery sequence hypointensity with diffuse white matter hyperintensity (figure 1C-D). Based on the clinical and radiological findings, a diagnosis of an infantile-onset GM2 gangliosidosis was concluded. Enzyme analysis showed deficient total hexosaminidase $(A+B)$ enzyme in plasma $(<0.062 \mathrm{nmol} / \mathrm{hour} / \mathrm{mg}$, normal range $660-5000 \mathrm{nmol} /$ hour $/ \mathrm{mg}$ ). Genetic counselling was offered to the parents. The patient succumbed to an intercurrent respiratory illness 2 months later. Sandhoff's disease is an autosomal-recessive lysosomal storage disorder due to hexosaminidase $\mathrm{A}$ and $\mathrm{B}$ enzyme deficiency (due to an abnormal $\beta$-subunit) leading to accumulation of glycosphingolipids in neuronal cells and subsequent neurodegeneration. ${ }^{1}$ Progressive systemic accumulation of sphingolipids leads to macrocephaly, cherry-red spots in the eye, skeletal dysostosis and organomegaly. ${ }^{2}$ It is unusual to see microcephaly in storage disorders and may cloud the clinical diagnosis. Anecdotal reports of microcephaly in 3 of the 18 Iranian patients with GM2 gangliosidosis support our finding. ${ }^{3}$ The index case presented with the classical features of bilateral cherry-red spot, skeletal storage and psychomotor arrest. In the absence of familial small head size or significant malnutrition, it is intriguing to see microcephaly in association with Sandhoff's disease. It may be attributed to the onset of significant neuronal loss in early infancy secondary to GM2 ganglioside deposition. Contrary to the classical teaching, our case highlights that the absence of macrocephaly or presence of microcephaly should not deter a clinician from suspecting GM2 gangliosidosis in the correct clinical context.

\section{Learning points}

- Infantile Sandhoff's disease may present with microcephaly.

- Absence of macrocephaly should not deter a clinician to diagnose Sandhoff's disease in the appropriate clinical context.

- Thalamic hypointensities on brain MRI are an important radiological clue.

Contributors KM: patient management, draft of manuscript. RSK: patient management, draft of manuscript. PS: analysis of radiological data, critical review of manuscript for intellectual content and final approval of the version to be published. AGS: patient management, critical review of manuscript for intellectual content and final approval of the version to be published.

Competing interests None declared.

Patient consent Obtained from guardian.

Provenance and peer review Not commissioned; externally peer reviewed.

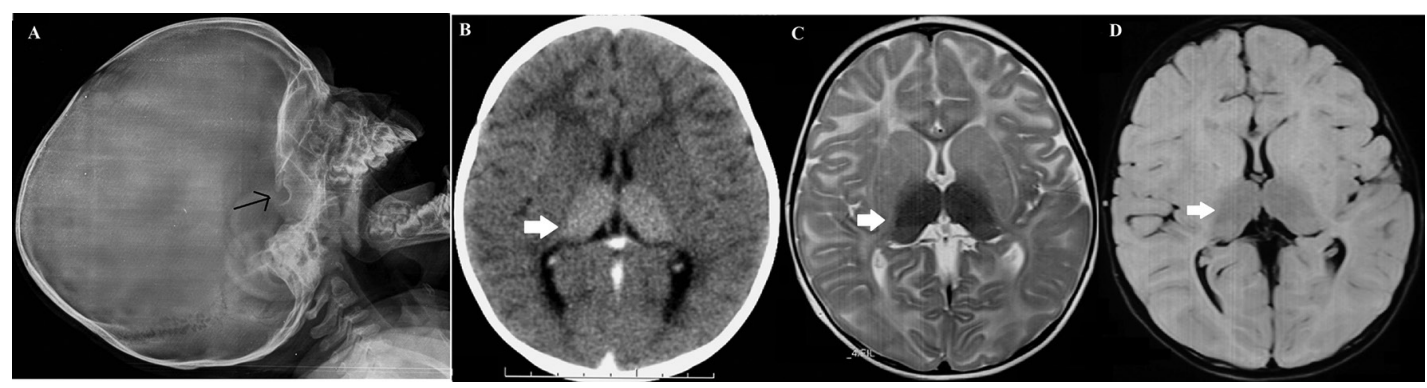

Figure 1 (A) Lateral skull radiograph showing the J-shaped sella turcica (arrow). (B) Contrast-enhanced CT scan of the brain showing bilateral hyperdense thalami (arrow) and abnormally hypodense white matter in bilateral frontal area in axial section. MRI (C) T2-weighted and (D) FLAIR axial sections showing bilateral hypointense thalami (arrows) and hyperintense periventricular and subcortical white matter consistent with GM2 gangliosidoses. 


\section{Images in...}

(c) BMJ Publishing Group Ltd (unless otherwise stated in the text of the article) 2017. All rights reserved. No commercial use is permitted unless otherwise expressly granted.

\section{REFERENCES}

1 Muralidharan CG, Tomar RP. Infantile Sandhoff disease: unusual presentation. Med J Armed Forces India 2016;72:S91-3.

Copyright 2017 BMJ Publishing Group. All rights reserved. For permission to reuse any of this content visit http://group.bmj.com/group/rights-licensing/permissions.

BMJ Case Report Fellows may re-use this article for personal use and teaching without any further permission.

Become a Fellow of BMJ Case Reports today and you can:

- Submit as many cases as you like

- Enjoy fast sympathetic peer review and rapid publication of accepted articles

- Access all the published articles

Re-use any of the published material for personal use and teaching without further permission

For information on Institutional Fellowships contact consortiasales@bmjgroup.com

Visit casereports.bmj.com for more articles like this and to become a Fellow
2 Kumar D, Ramanathan S, Khanna M, et al. Bithalamic T2 hypointensity: a diagnostic clue for Sandhoff's disease. Neurol India 2014;62:481-2.

3 Karimzadeh P, Jafari N, Nejad Biglari H, et al. GM2-Gangliosidosis (Sandhoff and Tay Sachs disease): diagnosis and neuroimaging findings (An Iranian Pediatric Case Series). Iran J Child Neurol 2014;8:55-60. 